\title{
Mike Davis
}

\section{Planet slumova}

\section{Zagreb, VBZ, 2011., 220 str.}

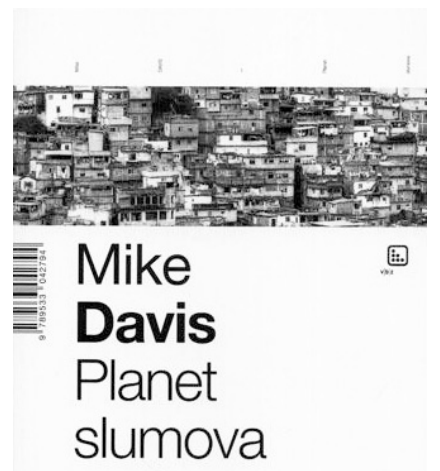

Umjesto gradova čija se svjetla uzdižu prema nebu, najveći dio urbanog svijeta 21. stoljeća čuči $u$ prljavštini, okružen zagađenjem, izmetom i truleži.

Bujanje megagradova u suvremenom društvu fenomen je koji danas stvara gradove s više od osam milijuna stanovnika te hipergradove s više od 20 milijuna žitelja što je, usporedbe radi, procijenjeno cjelokupno urbano stanovništvo svijeta u doba Francuske revolucije. U svom porastu gradovi stvaraju različite urbane mreže, koridore i hijerarhije, a jedna od posljedica takvog, ubrzanog širenja gradova je i sve veća nejednakost unutar i između gradova različitih veličina i ekonomskih situacija. Često se postavlja pitanje je li jaz koji je postojao u prihodima i razvoju između grada i sela danas nadomješten jednako fundamentalnim procjepom između malih gradova i divovskih metropolisa. Njihova sve rapidnija polarizacija uvelike utječe na pojavu slumova.

Klasična definicija karakterizira slum kroz prenatrpanost, loše ili neformalno stanovanje, neadekvatan pristup pitkoj vodi i sanitarnim uvjetima te nesigurnost posjeda. To je operativna definicija sluma, službeno prihvaćena na UN-ovom sastanku u Nairobiju 2002. godine. Ona je ograničena na fizičke i pravne karakteristike stanovanja te izbjegava teže mjerljive društvene dimenzije, iako ih u okvirima većine okolnosti izjednačava s postojanjem ekonomske i društvene marginalnosti stanovnika slumova. Oni danas čine $6 \%$ gradskoga stanovništva u razvijenim zemljama, no također i $78,2 \%$ stanovnika velegrada u najmanje razvijenim zemljama, što je u cijelosti jednako čak trećini globalnoga urbanog stanovništva. Najveći postotak žitelja slumova nalazi se u Etiopiji (čak 99,4\% urbanog stanovništva), Čadu (također 99,4\%), Afganistanu $(98,5 \%)$ i Nepalu (92\%).

Autor je ovu knjigu podijelio na osam poglavlja, epilog i kazalo. U prvim dvama poglavljima (Urbani klimakterij i Prevlast slumova) najprije upozorava na udvostručenje stanovništva u urbanim područjima na gotovo četiri milijarde u sljedećoj generaciji. Posljedica kolizije ruralnog i urbanog prostora do koje dolazi u nekim područjima svijeta (Jugoistočna Azija, Indija, Egipat, Zapadna Afrika) jest djelomi- 
ce urbanizirano seosko područje, „difuzni krajolik“ koji će odrediti 21. stoljeće u bogatim i siromašnim zemljama bez obzira na prijašnju urbanu povijest. Takva će nova ulančavanja postati policentrične mreže koje nemaju ni tradicionalne jezgre ni prepoznatljive periferije. U zemljama trećeg svijeta, nasuprot klasičnom stereotipu o radnom selu i industrijskom metropolisu, postoji mnoštvo primjera kapitalističkih odnosa na selu i radno deindustrijaliziranih gradova. Cijela seoska područja također su uništena, pa su gradovi, unatoč svojem stagnirajućem ili negativnom ekonomskom rastu i bez nužnih ulaganja u nove infrastrukture, obrazovne sustave ili sustavne javnog zdravstva, pretrpjeli tu svjetsku agrarnu krizu. Autor naglašava kako su gradovi budućnosti, umjesto od stakla i čelika, sagrađeni od polovnih cigla, slame, plastike, cementnih blokova i drvenih otpadaka. U Južnoj je Aziji, primjerice, studija kasnih 1980-ih pokazala kako se čak do 90\% rasta urbanih kućanstava odnosi na slumove. Crna ce Afrika 2015. godine imati 332 milijuna žitelja u slumovima, s tim da postoji više od 200.000 slumova na Zemlji s populacijom u rasponu od nekoliko stotina do više milijuna ljudi.

Autor također navodi tipologiju slumova koji se dijele na metropolitansku jezgru, koja može biti formalna (nastambe, domovi, hosteli) i neformalna (skvoteri i uličari), te periferiju, koja je također formalna (privatni najam i domovi) i neformalna (piratske parcele i skvoterske nastambe), a za kraj navodi i izbjegličke logore. Pojam periferije danas postaje relativan, vremenski specifičan termin budući da bi današnji urbani rub, granična gradska polja, šuma ili pustinja sutra mogli postati dio guste metropolitanske jezgre. Autor se u tom kontekstu također osvrće i analizira pojmove „piratske urbanizacije“, „nevidljivih unajmljivača“ i „urbanog ruba“.

U trećem poglavlju (Izdaja države) europski se kolonijalizam opisuje kao sustav kontrole urbanog rasta kao i azijski staljinizam koji je pokušao zaustaviti priljev stanovništva iz seoskoga u gradska područja. Slične su kontrole nad ruralno-urbanom migracijom tijekom 1950-ih uvedene i u Sjevernoj Koreji, Albaniji, Sjevernom Vijetnamu i Latinskoj Americi. Autor napominje i kako su od javne i državno potpomognute stanogradnje u Trećem svijetu korist imale primarno urbana srednja klasa i elite.

Četvrto poglavlje (Iluzije samopomoći) raspravlja suradnju Svjetske banke, Programa za razvoj Ujedinjenih naroda i drugih humanitarnih organizacija s regionalnim i nevladinim organizacijama (NGO-ima) u svrhu potpomaganja urbanog razvoja. Također komentira razvoj i ulogu nevladinih organizacija u tom kontekstu.

Peto poglavlje naslova Haussman u tropima započinje citatom „Čini se da temeljni uzrok urbanog života u slumovima nije urbano siromaštvo već urbano bogatstvo“ i time nas upućuje na problem povećanja urbane nejednakosti u zemljama Trećeg svijeta. Bombay je, primjerice, ekstrem u kojem bogati žive na 90\% zemlje, a siromašni na ostatku od 10\%. Takvi polarizirani obrasci korištenja zemlje rekapituliraju stariju logiku imperijalne kontrole i rasne prevlasti. U urbanom dijelu Trećeg svijeta česta je i pojava „čišćenja“ slumova uslijed nekog važnog događaja: konferencija, posjeta visokih dostojanstvenika, sportskih događaja, pri čemu se žitelje slumova 
izbacuje iz njihovih domova. Od sredine 1970-ih bilo je uobičajeno da vlade širom svijeta čišćenje slumova opravdavaju izgovorom da je to bilo nezaobilazno sredstvo u borbi protiv kriminala budući da su slumovi nevidljivi za državni nadzor. Čišćenje slumova u nekim je slučajevima prešlo u otvorene napade na stanovnike slumova, pa je, recimo, u Zimbabveu provedena operacija pod nazivom „Istjerajte smeće“ u kojem policija nije prezala ni od strijeljanja ljudi. U slučajevima u kojima se siromašni ogorčeno opiru deložaciji iz urbane jezgre dobro situirani stanovnici dobrovoljno mijenjaju svoje stare četvrti za ograđene bajkovite parcele na periferiji. Njihove su kuće pretvorene u utvrde koje okružuju visoki zidovi na čijim su vrhovima krhotine stakla i bodljikava žica a na svim prozorima teške željezne rešetke. U nekim slučajevima grade se ograde kojima teče struja od tisuću volta.

Poglavlje Slumovska ekologija približava nam ekološke uvjete u kojima žive stanovnici slumova, od loše geologije koja ima za posljedicu potrese, odrone, požare i poplave do raznoraznih patologija urbanih oblika do kojih dolazi zbog sinergije mnogostrukih toksina na istoj lokaciji. Dolazi i do pojave kolizije između urbanog stanovništva i prometne zakrčenosti koja rezultira raznim stradanjima, pa tako u Trećem svijetu svake godine više od milijun ljudi pogiba u prometnim nesrećama. U Delhiju se Hindustan Times požalio da se pripadnici srednje klase koji putuju na posao rijetko kad trude zaustaviti nakon što pregaze beskućnike ili siromašnu djecu. Također, siromašni gradovi na svakom kontinentu nisu ništa više od začepljenih i preplavljenih kanalizacijskih odvoda što autor živopisno opisuje u potpoglavlju Živjeti u gounima.

Sedmo poglavlje nosi naslov SAPiranje Trećeg svijeta i evaluira uvođenje Strukturalnog programa prilagodbe (SAP-a) po nalogu Međunarodnog monetarnog fonda koji, po mišljenju autora, predstavlja veliku prirodnu katastrofu, dok u posljednjem poglavlju (Višak čovječanstva) autor prikazuje situacije dječjeg rada u kojima djeca rade po dvanaest ili više sati dnevno u uvjetima fizičkog i psihičkog zlostavljanja te također upozorava na tržište organima u zemljama Trećega svijeta. Ukazuje se i na pojavu „djece vještica“, tj. djece iz Kinshase iz najnižih slojeva koju se optužuje za vještičarenje. Danas djeca vještice iz Kinshase te slumovi u Indiji i Egiptu iz kojih se izvoze ljudski organi predstavljaju najnižu egzistencijalnu razinu iza koje postoje samo logori smrti i gladovanja.

U epilogu pod naslovom Vijetnamskom ulicom autor postavlja pitanje o potencijalnim pobunama siromašnih i obezvlaštenih i pita se nisu li slumovi samo vulkani koji čekaju erupciju. Smatra kako ova pitanja treba istražiti pomoću konkretnih, usporednih studija slučaja prije nego se na njih može odgovoriti u bilo kojem općenitom smislu. Unutar svakog pojedinog grada dolazi do različitih reakcija na slumovsku populaciju i zbunjujuće raznovrsnosti reakcija na njihovo strukturalno zanemarivanje i deprivaciju: od karizmatičnih crkava i proročkih kultova do etničkih policija, uličnih bandi, neoliberalnih nevladinih organizacija i revolucionarnih društvenih pokreta. S druge strane, rubni gradovi u svojoj „pozlaćenoj uhvaćenosti“ stvaraju stanovnike koji prestaju biti „građani svoje zemlje“ i postaju „nomadi koji pripadaju nadzemaljskoj topografiji novca i njoj duguju odanost“. Istovremeno, u stvarnom svijetu, sirotinja je zablaćena u slumu. 
Ova je knjiga oštra kritika neoliberalnog kapitalizma u kojoj se bez uljepšavanja prikazuje život ljudi u slumovima, siromaštvo i sve njegove devastirajuće posljedice do čega dolazi zbog sve veće polarizacije bogatih i siromašnih. Budućnost ljudske solidarnosti, prema autoru, ovisi upravo o militantnom odbijanju nove urbane sirotinje da prihvati vlastitu terminalnu marginalnost unutar globalnog kapitalizma pa knjiga tako završava citatom koji nekada distopijsku budućnost čini zastrašujuće realnom sadašnjošću:

„Svake noći, stršljenasti naoružani helikopteri vrebaju enigmatične neprijatelje u uskim uličicama slumovskih okruga, sijući pakleni oganj po straćarama ili automobilima u bijegu. Svako jutro slumovi odgovaraju bombašima samoubojicama i snažnim eksplozijama. Ako imperij može razviti orvelovske tehnologije represije, njegovi izopćenici imaju bogove kaosa na svojoj strani."

Jelena Zlatar

Institut za društvena istraživanja u Zagrebu 